\begin{tabular}{|c|c|c|}
\hline \multirow[b]{2}{*}{ FYCEI I ENT } & $\begin{array}{l}\text { International Journal of Current Research in } \\
\text { Biosciences and Plant Biology }\end{array}$ & $E$ \\
\hline & Volume $5 \bullet$ Number 8 (August-2018)・ ISSN: 2349-8080 (Online) & 5 \\
\hline $\begin{array}{l}\text { EXCELLENT } \\
\text { PUBLISHERS }\end{array}$ & Journal homepage: www.ijcrbp.com & 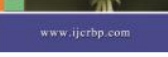 \\
\hline
\end{tabular}

\title{
Comparison of Length-Weight Relationship of Bombay Duck (Harpadon nehereus) between Juata and Amal
}

\author{
Amrullah Taqwa ${ }^{*}$, Syamsu Alam Ali ${ }^{2}$, M. Natsir Nessa ${ }^{2}$ and \\ Andi Niartiningsih ${ }^{2}$
}

\begin{abstract}
${ }^{1}$ Faculty of Marine Science and Fishery Borneo University, Tarakan, Indonesia ${ }^{2}$ Faculty of Marine Science and Fishery Hasanuddin University, Makassar, Indonesia
\end{abstract}

${ }^{*}$ Corresponding author.

\begin{tabular}{|c|c|}
\hline Article Info & ABSTRACT \\
\hline $\begin{array}{l}\text { Date of Acceptance: } \\
15 \text { July } 2018\end{array}$ & \multirow{4}{*}{$\begin{array}{l}\text { The length-weight relationship of Harpadon nehereus was analyzed. Samples were } \\
\text { collected from November } 2016 \text { to January } 2017 \text {, in Juata and Amal at Tarakan, North } \\
\text { Borneo, Indonesia. The total length measured using a ruler scale } 1 \mathrm{~mm} \text {. The total } \\
\text { weight measured using a digital platform scales with an accuracy of } 1 \text { gr. The length- } \\
\text { weight equation, based on } 600 \text { unsexed individuals, was } \mathrm{W}=0.006{ }^{*} \mathrm{~L}^{2.59} \text { at Juata and } \\
\mathrm{W}=0.005^{*} \mathrm{~L}^{3.00} \text { at Amal where } \mathrm{W} \text { is the total weight }(\mathrm{g}) \text { and } \mathrm{L} \text { is the total length }(\mathrm{cm}) \text {. } \\
\text { In general the size of fish in Juata is greater than fish in Amal, but fish in Amal are } \\
\text { with more fat. The } t \text {-test results in both sites showed that Nomei growth was } \\
\text { isometric ( } \alpha=0.05) \text {. A coefficient of determination value of the length-weight } \\
\text { relationship in Juata and Amal has } 0.93 \text { and } 0.88 \text { respectively. }\end{array}$} \\
\hline $\begin{array}{l}\text { Date of Publication: } \\
06 \text { August } 2018\end{array}$ & \\
\hline Keywords & \\
\hline $\begin{array}{l}\text { Commercial fish } \\
\text { Harpadon nehereus } \\
\text { Length-weight relationship }\end{array}$ & \\
\hline
\end{tabular}

\section{Introduction}

Harpadon nehereus catching in Tarakan waters has been done since ten years ago and its production output keeps increasing from year to year, and there has been no management of arrest. In 2001 the production amount 58.8 tons, in 2007 increased to 73.5 tons, in 2010 increased to 84.9 tons, then in 2014 increased to 150 tons (Department of

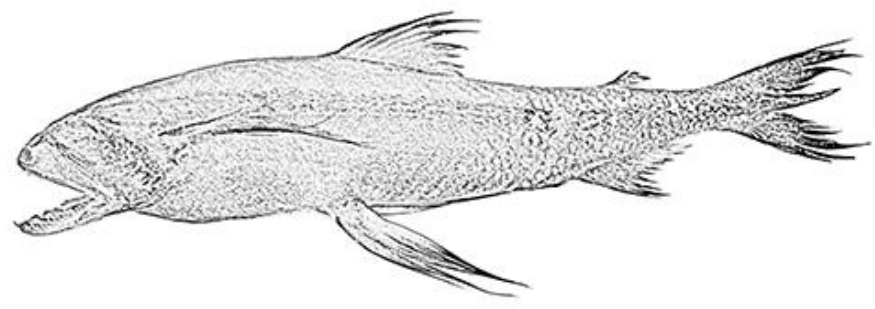
Fisheries of Tarakan City, 2015).

Fig. 1: Bombay duck (H. nehereus). 
$H$. nehereus is one of the most important commercial fish consumed. The catches consumed in fresh condition only a small amount of the total, the rest processed into a dry form for national and international markets (DG Directorate General of Wild Fisheries, 2014). H. nehereus catch in Indonesia was 12,200 tons in 1990 and increased to 15,200 tons in 1995 (Carpenter and Niem, 1999). Nomei fish production in the world from 2011 to 2014 respectively 225,306 tons; 207,569 tons; 257,384 tons; 277,119 tons and 257.206 tons (FAO, 2016). Fishermen provide information that the size of fish caught is likely to be smaller, indicating that Nomei fish has been under pressure in capture. Given the facts that the catch was increased year by year and size of fish to be smaller, the management of $H$. nehereus needs to be done. This management policy must be supported by a scientific basis in the form of accurate data. Data of ecobiology aspect is one of the aspects needed in fisheries management.

In Juata, H. nehereus were caught by trawl for 3-4 days during neap tide period (on 7 - 10 and 21 - 24 moon day), while in Amal waters, H. nehereus were caught by trap net for 7 days (on 1 - 4, 12 18 , and 27 - 30 moon day).

In this paper, we compared the length-weight relationship of $H$. nehereus caught in Juata and Amal waters.

\section{Materials and methods}

The length $(\mathrm{cm})$ and weight $(\mathrm{g})$ of $H$. nehereus were collected at Juata and Amal waters, Tarakan, North Borneo, Indonesia from November 2016 to January 2017 (Fig. 2). These samples were collected from fishermen. Sampling has been done every tidal period (twice every month).

$H$. nehereus were caught by trawl in Juata, and by trap net in Amal. The total length measured by a 1 $\mathrm{mm}$ scale ruler. The total weight is measured by electric scales with a precision of $1 \mathrm{~g}$.

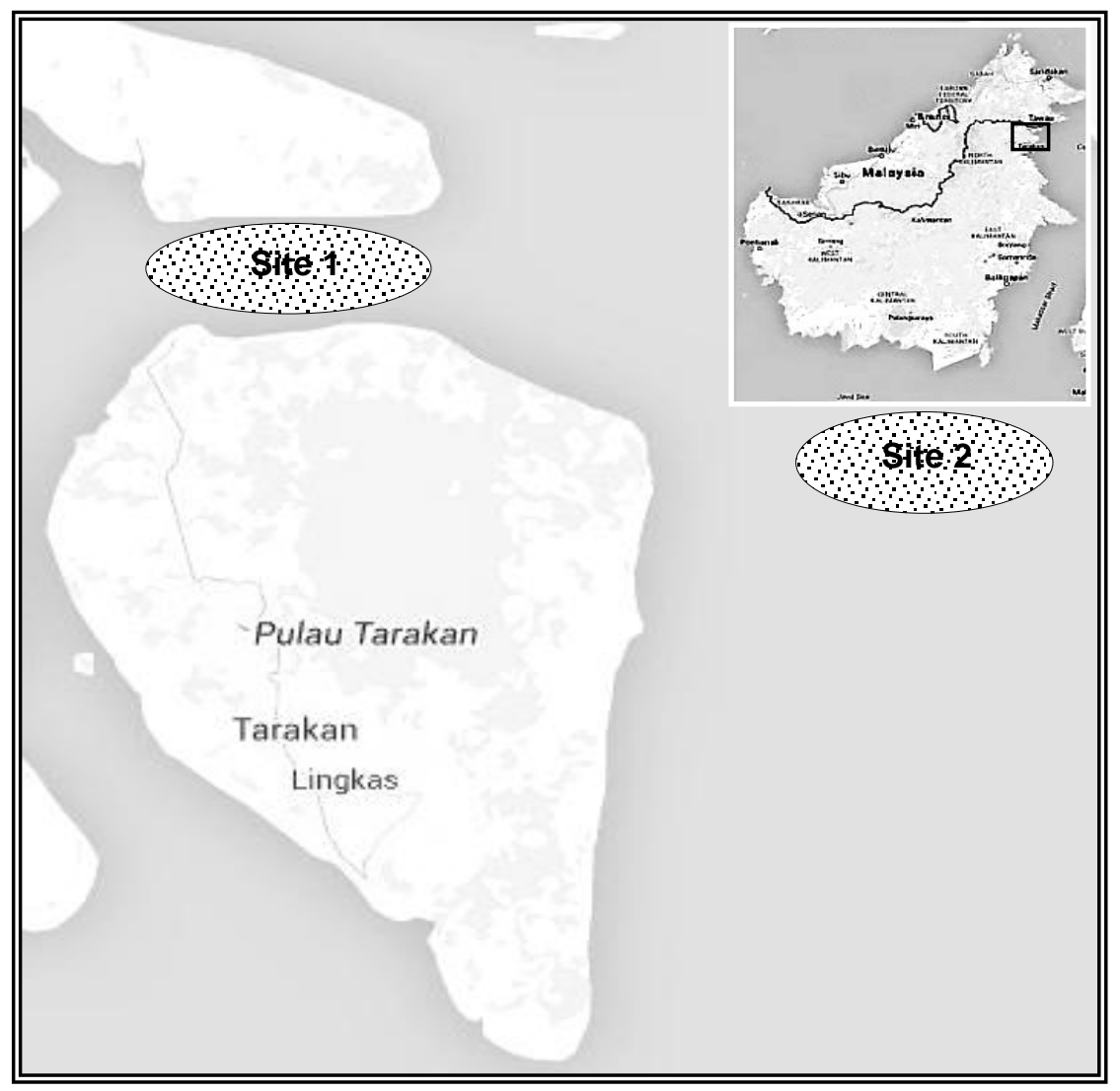

Fig. 2: Sampling sites. Site 1. Juata and Site 2. Amal. 


\section{Data analysis}

The length-weight relationship of $H$. nehereus estimated using the formula $\mathrm{W}=\mathrm{aL}^{\mathrm{b}}$ (Le Cren, 1951), where: $\mathrm{W}=$ total weight ( $\mathrm{g}$ ) of the fish, $\mathrm{L}=$ total length (cm) of fish, $a$ and $b$ are the constants. The constants $a$ and $b$ in the equation were estimated using Microsoft Excel.

The $t$-test was used by dividing the differences between $b$ and 3 by standard error of $b$ to the whether the regression coefficient significantly deviated from the expected cubic value.

The $t$-test formula (Pauly, 1984):

$$
\mathrm{t}=\frac{\mathrm{sd}_{\mathrm{x}}}{\mathrm{sd}_{\mathrm{y}}} \cdot \frac{|b-3|}{\sqrt{1-\mathrm{r}^{2}}} \times \sqrt{\mathrm{n}-2}
$$

Where, $s d_{x}$ is the standard deviation of the $\log \mathrm{L}$ values, and $\mathrm{sd}_{\mathrm{y}}$ the standard deviation of the $\log \mathrm{W}$ values, $\mathrm{n}$ being the number of fish used in the computation. The value of $b$ is different from 3 if $t$ is greater than the tabled value of $t$ for $n-2$ d.f.

\section{Results and discussion}

The summary of total length-weight relationships of $H$. nehereus based on 300 individuals each site. The range of the total length and weight at Juata and Amal were given in Table 1.

Table 1. The range of the total length and weight at both sites.

\begin{tabular}{lll}
\hline Site & Length $(\mathbf{c m})$ & Weight $(\mathbf{g})$ \\
\hline Juata & $15.6-25.4$ & $19.3-122.8$ \\
Amal & $13.1-27.5$ & $18.1-116.8$ \\
\hline
\end{tabular}

The length-weight relationship was determined by the following equation $W=0.006 * L^{2.95}$ at Juata and $W=0.005 * L^{3.00}$ at Amal (Fig. 3). In general the size of fish in Juata is greater than fish in Amal, but fish in Amal are with more fat. The $t$-test results in both sites showed that Nomei growth was isometric $(\alpha=0.05)$. In general, the value of $b$ depends on the physiological, environmental, geographic conditions, sampling techniques, biological conditions and food availability (Jenning et al., 2001; Froese, 2006). Muchlisin (2010) states that the size of the value of $b$ is also influenced by fish behavior.

A coefficient of determination value of the lengthweight relationship in Juata and Amal has 0.93 and 0.88 respectively. High coefficient of determination value shows a close relationship between weight gain with increasing length and vice versa. The determinant coefficient value of $88 \%$ to $93 \%$ of the total weight gain variant can be explained by the graph of the length-weight relationship. The observations show that $H$. nehereus have a compressed, compact body shape, in addition to fat caused by long increments, but also due to height.

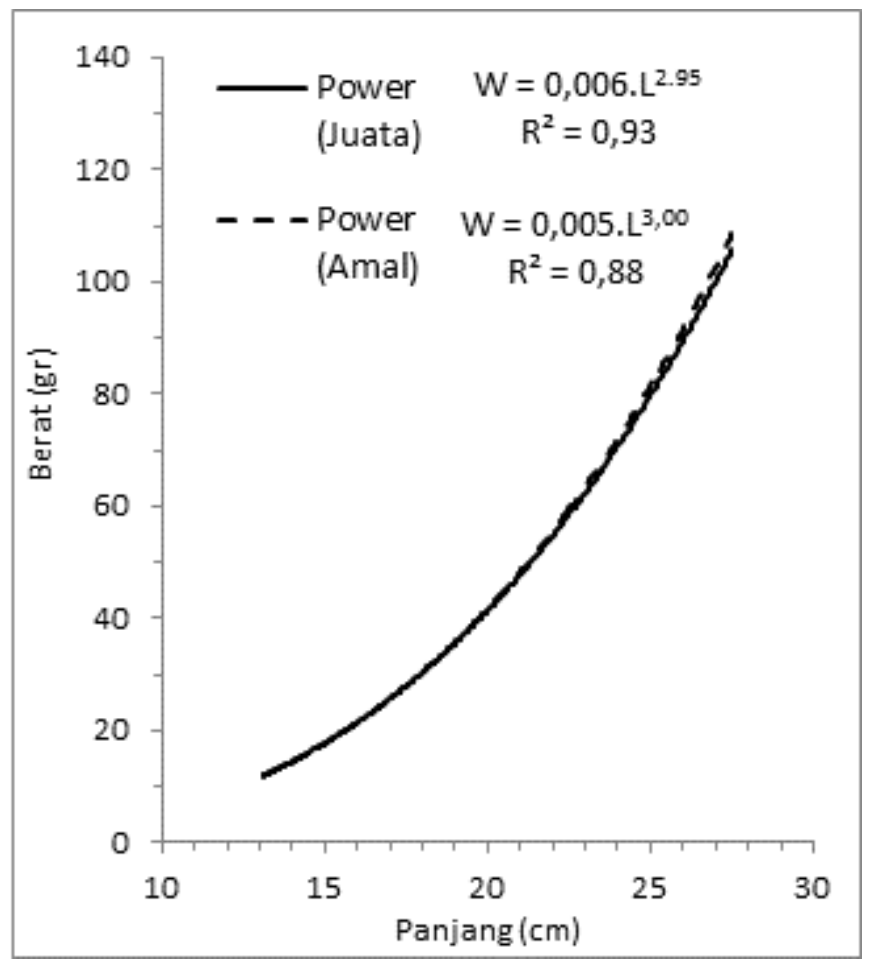

Fig. 3: Length-weight relationship.

Growth is influenced by many factors both internal and external factors. External factors include the amount and size of available food, the number of fish using available food sources, temperature, dissolved oxygen, ammonia levels in the water and salinity (Moyle and Cech, 1988). 


\section{Conclusion}

In general the size of fish in Juata is greater than fish in Amal, but fish in Amal are with more fat. The length-weight relationship showed that $H$. nehereus growth was isometric $(\alpha=0.05)$.

\section{Conflict of interest statement}

Authors declare that they have no conflict of interest.

\section{References}

Carpenter, K.E., Niem, V.H., 1999. FAO Species Identification Guide for Fishery Purposes. The Living Marine Resources of the Western Central Pacific. Vol. 3, Batoid Fishes, Chimaeras and Bony Fishes Part 1 (Elopidae to Linophrynidae), FAO, Rome.

Department of Fisheries of Tarakan City. 2015. Statistic of Fisheries of Tarakan.

Directorate General of Wild Fisheries. 2014. Harpodon nehereus. Ministry of Marine Affairs and Fisheries Republic of Indonesia. Jakarta.

FAO, 2016. Fishery and Aquaculture Statistics 2014. FAO.
Froese, R., 2006. Cube law, condition factor and weight length relationship: History, metaanalysis and recommendations. J. Appl. Ichthyol. 22, 241-253.

Jennings, S., Kaiser, M. J., Reynolds, J. D., 2001. Marine Fishery Ecology. Blackwell Sciences, Oxford.

Le Cren, E.D., 1951. The length-weight relationships and seasonal cycle in gonad weight and condition in the perch (Perca fluviatilis). J. Anim. Ecol. 20, 201-219.

Moyle, P. B., Cech, J. J., 1988. Fishes: An Introduction to Ichthyology. $2^{\text {nd }}$ Edn. Prentice Hall Inc., USA.

Muchlisin, Z.A., 2010. Diversity of Freswater Fishes in Aceh Province, Indonesia with Emphasis on Several Biological Aspects of The Depik (Rasbora tawarensis) An Endemic Species in Lake LautTawar. Doctoral thesis (unpublished). Malaysia University of Science. Penang.

Pauly, D., 1984. Fish Population Dynamics in Tropical Waters: A Manual for Use with Programmable Calculators. ICLARM Contribution No. 143. ICLARM, Manila.

Sparre, P., Venema, S. C., 1998. Introduction to Tropical Fish Stock Assessment - Part 1: Manual. FAO - FIAT PANIS. Rome.

\section{How to cite this article:}

Taqwa, A., Ali, S. A., Nessa, M. N., Niartiningsih, A., 2018. Comparison of length-weight relationship of Bombay duck (Harpadon nehereus) between Juata and Amal. Int. J. Curr. Res. Biosci. Plant Biol. 5(8), 11-14. doi: https://doi.org/10.20546/ijcrbp.2018.508.002 